\title{
Kajian Etnosains Pada Potensi Penggunaan Saliva untuk Penyembuhan Luka Ringan di Lampung
}

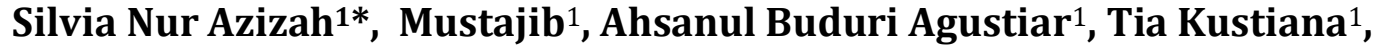 Hafidha Asni Akmalia ${ }^{1}$}

\author{
${ }^{1}$ Program Studi Pendidikan Biologi, Fakultas Sains dan Teknologi \\ UIN Walisongo Semarang, 50181-Indonesia
}

\begin{abstract}
Traditional medicine is the local wisdom of the Indonesian people. The people of the Jaya Sakti area of Central Lampung use saliva as a medicine to heal minor wounds. This study aims to determine the potential use of saliva in healing minor wounds. This study uses the method of observing the community. The results showed that based on the percentage of data from field observations related to the use of saliva for minor injuries in communities around Jayasakti village, Anak Tuha District, Central Lampung Regency, it is known that most people have used saliva to treat minor wounds, while other communities have never used it. or seeing other people use saliva as a remedy for minor wounds. Based on the literature review, the content contained in saliva, especially histatin, plays a major role in improving wound healing by increasing the revitalization phase, especially through increasing keratinocyte migration and proliferation. Besides, people use saliva as a medicine to heal minor wounds because they follow the habits of people who have been passed down from generation to generation and already know the content of saliva that can heal minor wounds, namely histatin and alkaline acids. In conclusion, saliva is effective to use as a wound-healing drug because of the compounds contained in saliva and people's experiences when using it.
\end{abstract}

Keywords: growth factors; wound; saliva.

\begin{abstract}
Abstrak
Pengobatan tradisional merupakan kearifan lokal bangsa Indonesia. Masyarakat daerah Jaya sakti Lampung Tengah menggunakan saliva sebagai obat untuk menyembuhkan luka ringan. Tujuan penelitian ini adalah untuk mengetahui potensi penggunaan saliva pada penyembuhan luka ringan. Penelitian ini menggunakan metode observasi terhadap masyarakat. Hasil penelitian menunjukan bahwa berdasarkan presentase data hasil observasi lapangan terkait penggunaan saliva untuk obat luka ringan pada masyarakat di sekitar desa Jayasakti, Kecamatan anak Tuha, Kabupaten Lampung Tengah, diketahui bahwasannya sebagian besar masyarakat pernah menggunkan saliva untuk mengobati luka ringan, sedangkan masyarakat lainnya tidak pernah menggunakan atau melihat orang lain menggunakan saliva sebagai obat penyembuh luka ringan. Berdasarkan kajian literatur, kandungan yang terdapat pada saliva terutama histatin berperan utama dalam meningkatkan penyembuhan luka dengan meningkatkan fase repitelisasi, terutama melalui peningkatan migrasi dan proliferasi keratinosit. Selain itu masyarakat menggunakan saliva sebagai obat penyembuh luka ringan karena mengikuti kebiasaan masyarakat yang sudah turun-temurun serta sudah mengetahui kandungan saliva yang dapat menyembuhkan luka ringan yaitu histatin dan asam basa. Berdasarkan hasil penelitian in saliva dinilai efektif untuk digunakan sebagai obat penyembuh luka karena senyawa yang terkandung didalam saliva dan pengalaman masyarakat ketika menggunakannya.
\end{abstract}

Kata kunci: faktor pertumbuhan; luka; saliva.

\footnotetext{
* Coressponding: Silvia Nur Azizah, email: silviaaazizah@gmail.com, Program Studi Pendidikan Biologi, Fakultas Sains dan Teknologi UIN Walisongo Semarang, 50181-Indonesia.
}

Copyright (C) 2021 Al-Hayat: Journal of Biology and Apllied Biology 


\section{Pendahuluan}

Kearifan lokal bangsa Indonesia sangat beragam, hal ini tercerminkan dari pikiran, sikap, perilaku, dan tindakan yang merupakan hasil dari budaya yang dimiliki termasuk dalam bidang kesehatan. Setiap etnis pada Bangsa Indonesia memiliki kearifan lokal termasuk obat tradisional yang digunakan untuk menyembuhkan orang sakit. Obat tradisional yang digunakan oleh masyarakat Indonesia bermacam-macam tergantung pada daerah dan sukunya. Hal ini terjadi karena keanekaragaman hayati disetiap daerah berbeda, sehingga obat tradisional yang di gunakan untuk menyembuhkan penyakit juga berbeda. Keanekaragaman hayati inilah yang bisa menjadi potensi untuk memberikan kesembuhan dan me-nyelesaikan masalah yang terjadi disuku tersebut (Darmastuti, 2011).

Kata Etnosains (Ethnoscience) berasal dari bahaya yunani yaitu ethos yang berarti bangsa dan bahasa latin yaitu scienta yang berarti pengetahuan. Berdasarkan pengertian tersebut etnosains adalah suatu pengetahuan yang dimiliki suatu suku, bangsa atau kelompok tertentu yang dianut sebagai pengetahuan khas dari budaya yang diberikan(Pertiwi \& Rusyda Firdausi, 2019). Jadi dapat disimpulkan bahwasannya kajian etnosains adalah sebuah penelitian yang menghubungkan antara pengetahuan sains dan pengetahuan budaya masyarakat lokal di suatu daerah tertentu. Pengetahuan berbasis etnosains digunakan oleh masyarakat secara turun temurun sesuai kearifan lokal disetiap daerah. Seperti pengetahuan etnosains yang ada di daerah sekitar desa Jayasakti, Kecamatan Anak Tuha, Kabupaten Lampung Tengah. Masyarakat Lampung Tengah menggunakan saliva sebagai obat untuk mengobati luka ringan, masyarakat mendapatkan informasi tersebut dari orang tua mereka, karena pengetahuan ini merupakan suatu kearifan lokal yang ada di Indonesia yang merupakan suatu Negara yang menjaga dan melestarikan kearifan lokalnya.

Salah satu obat tradisional yang digunakan oleh manusia sejak zaman dahulu adalah saliva. Penggunaan saliva dalam penyembuhan luka yang digunakan dengan cara menjilati luka kulit oleh hewan dan manusia merupakan peristiwa yang sudah diketahui sejak lama yang efektif dalam meningkatkan penyembuhan luka kulit (Oudhoff et al., 2009). Menurut Verrier L., (1970) dalam Brand et al., (2014) menjilati luka adalah naluri bagi hewan dan manusia. Bahkan ada laporan bahwa nelayan Fiji mengizinkan anjing menjilati luka mereka untuk mempercepat penyembuhan luka. Selain itu, Neves et al., (2019) dan (Gibbs et al., 2019) juga menyatakan bahwa ketika terjadi luka ringan pada anggota tubuh, secara spontan orang yang terkena luka akan memberikan saliva pada luka tersebut. Masyarakat Yunani kuno sekitar 2.000 tahun yang lalu juga menggunakan saliva dalam penyembuhan luka, namun mereka menggunakan saliva ular. Pengetahuan mengenai penggunaan saliva dalam penyembuhan luka ringan berawal dari pengamatan pada perilaku hewan. Saat terkena luka, sebagian hewan menjilati luka tersebut, perilaku tersebut ternyata dapat memicu proses penyembuhan luka pada hewan tersebut.

Beberapa kelompok etnis di Afrika juga menggunakan saliva dalam proses penyembuhan dan pengobatan berbagai penyakit. Saliva yang dikombinasikan dengan tumbuhan lokal dipercaya memiliki khasiat sebagai obat. Pada masyarakat Somalia, air liur digunakan dalam pengobatan semua bentuk penyakit, seperti luka yang tidak kunjung sembuh dan bernanah, pengobatan untuk gigitan ular atau sengatan kalajengking (dalam hal ini, air liur dicampurkan dengan mentega dan dioleskan pada luka tersebut), dan lain sebagainya. Demikian pula, di antara suku Azande di Sudan, air liur digunakan sebagai aplikasi pertolongan pertama pada luka dan lecet. Di antara beberapa kelompok etnis, jamu dikunyah dan campuran air liur dan jamu ditempelkan pada luka. Di Tanzania, di antara suku Bena, untuk pengobatan bisul, tabib mengunyah ramuan tradisional (mhefefa dan munepa) dan selanjutnya menggunakan herba yang dikunyah dan dilunakkan untuk mengobati luka. Di antara suku Masai Afrika Timur, sari tumbuhan ol giloriti (Acacia abyssinica) dikunyah dan diludahi ke luka oleh tabib sebagai astringent. Begitu pula untuk penyembuhan pembengkakan, maka tanaman dikunyah ol agaram (Crossandra nilotica) lalu ditempatkan di daerah yang bengkak dan seorang ibu akan menempatkan pasta yang dikunyah dari tanaman ofe, $n$ gilo dan no orekum (Spilanthes acmella L.) pada lubang hidung seorang anak kecil yang hidungnya telah digigit lalat. 
Sejumlah penelitian di Afrika melaporkan penggunaan meludah sebagai bentuk pengobatan dengan penyembuh tradisional dengan cara meludahi pasien, hal ini ditemukan di antara Masai dan Somalia di Afrika Timur. Sebagai bagian dari upacara pemberkatan yang dilakukan oleh seorang yang beragama (wadaad) atau orang awam di antara orang Somalia, orang yang sakit diharuskan diludahi untuk mentransfer berkat(Wojcicki, 2003).

Berdasarkan penelitian yang dilakukan oleh Lesmana et al., (2018); Fajarwati et al. (2015); Wahyudi et al., (2013); (Abbasian et al., 2010); Oudhoff et al., (2009); Kavanagh \& Dowd, (2004), saliva efektif dalam mempercepat penyembuhan luka. Saliva memiliki kemampuan untuk mempercepat fase proliferasi penyembuhan luka dikarenakan faktor pertumbuhan yang terkandung di dalamnya. Hal tersebut diperkuat oleh pendapat Kumar et al., (2017) bahwa saliva memiliki peran alternatif dalam penyembuhan luka dengan cara mempercepat pembekuan darah.

Pengetahuan ini ternyata juga di-temukan dan dimanfaatkan oleh sebagian besar masyarakat di sekitar desa Jayasakti, Kecamatan Anak Tuha, Kabupaten Lampung Tengah secara turun temurun mempercayai bahwa saliva dapat digunakan dalam penyembuhan luka ringan. Cara tradisional ini diwariskan dari nenek moyang hingga generasi saat ini, namun alasan masyarakat di sekitar desa Jayasakti, Kecamatan Anak Tuha, Kabupaten Lampung Tengah dalam menggunakan saliva sebagai obat penyembuh luka ringan belum diketahui dengan jelas secara ilmiah. Maka dari itu perlu dilakukan penelitian kajian etnosains pada potensi penggunaan saliva untuk penyembuhan luka dan menganalisisnya menggunakan literature ilmiah sehingga dapat meluruskan alasan kurang tepat yang berkembang di masyarakat.

Tujuan dari penelitian ini adalah untuk mengetahui potensi penggunaan saliva pada penyembuhan luka ringan. Penelitian ini perlu ditindaklanjuti dengan kajian mengenai saliva orang-orang dengan kondisi fisiologis yang berbeda dan uji coba efektivitasnya pada responden terpilih.

\section{Metode Penelitian}

Metode penelitian yang digunakan adalah metode kualitatif yakni dengan melakukan observasi dan wawancara. Penelitian ini menggunakan metode observasi tertutup karena tidak berinteraksi secara langsung dengan subjek penelitian. Selain itu juga penelitian ini menggunakan metode wawancara dengan menggunakan kuisioner yang diberikan kepada subjek penelitian untuk mengetahui responnya. Observasi dilakukan di daerah Jaya sakti, Kecamatan Anak Tuha, Kabupaten Lampung Tengah pada bulan September 2020. Sampel yang digunakan adalah masyarakat sekitar sebanyak 32 orang yang terdiri dari 21 berjenis kelamin wanita dan 11 berjenis kelamin laki-laki dengan rentang usia 18-45 tahun. Observasi dilakukan dengan cara memberikan kuisioner kepada masyarakat sekitar. Setelah seluruh sampel mengisi kuisioner, selanjutnya dilakukan analisis data.

Data hasil penelitian dianalisis menggunkan metode content analisis. Metode content analisis yang digunakan adalah telaah pustaka, dimana penulis mengumpulkan berbagai sumber yang membahas terkait penggunaan saliva sebagai obat luka (Moleong, 2012).

\section{Hasil Penelitian dan Pembahasan}

\section{Saliva Sebagai Obat Penyembuh Luka Ringan}

Tradisi merupakan kegiatan tradisional yang diwariskan oleh nenek moyang dari generasi ke generasi. Tradisi turun menurun erat kaitannya dengan suatu kegiatan yang dilakukan oleh masyarakat, seperti kebiasaan mengobati luka ringan dengan saliva pada masyarakat disekitar desa Jayasakti, Kecamatan anak Tuha, Kabupaten Lampung Tengah. Pada saat mengalami luka, sebagian besar orang secara refleks mengoleskan saliva pada luka tersebut. Berdasarkan beberapa penelitian menjelaskan, bahwasannya pembentukan kelenjar ludah dimulai pada awal fase kehidupan fetus (janin) yang masih berumur 4-12 minggu, sebagai invaginasi epitel mulut yang akan berdiferensiasi kedalam duktus dan jaringan asinar (Rahmawati et al., 2015). 
Tabel 1

Penggunaan saliva untuk penyembuhan luka ringan di masyarakat Lampung Tengah

\begin{tabular}{clcc}
\hline No. & Pertanyaan penggunaan saliva untuk penyembuhan luka ringan & \multicolumn{2}{c}{ Persentase $\%$} \\
\hline 1 & Pernah melakukan/melihat orang lain menggunakan air liur & $93,55 \%$ & $6,45 \%$ tidak \\
& sebagai obat penyembuh luka & pernah & pernah \\
2 & Saliva milik siapa yang digunakan untuk penyembuhan luka & $70,77 \%$ & $29,03 \%$ \\
& & milik & saliva orang \\
& & sendiri & tua \\
3 & Kefektifan penggunaan saliva orang yang lebih & $41,94 \%$ & $58,06 \%$ \\
& tua(bapak/ibu/nenek/kakek dll) & Efektif & Tidak \\
& & & efektif \\
\hline
\end{tabular}

Saliva atau biasa disebut air liur merupakan cairan sekresi eksokrin yang dihasilkan oleh kelenjar ludah. Saliva merupakan cairan oral yang kompleks dan tidak berwarna dan kompleks. Saliva terdiri dari kombinasi sekresi yang bersumber dari kelenjar ludah besar dan kecil yang terletak pada mukosa oral. Kelenjar ludah berfungsi untuk mencerna makanan dengan mengeluarkan sekret atau saliva (Rahmawati et al., 2015). Saliva dihasilkan oleh tiga pasang kelenjar saliva minor dan kelenjar saliva mayor pada mukosa(Susanti, 2016).

Berdasarkan Tabel 1 tanggapan responden terhadap potensi penggunaan saliva untuk penyembuhan luka ringan di masyarakat Lampung Tengah diketahui bahwa 93,55\% masyarakat pernah menggunakan /melihat orang lain menggunakan saliva untuk mengobati luka ringan, sedangkan 6,45\% tidak pernah melakukan /melihat orang lain menggunakan saliva sebagai obat penyembuhan luka.

Pada penyembuhan luka ringan dengan menggunakan saliva sebanyak 70,97\% responden menggunakan saliva milik dirinya sendiri, sedangkan 29,03\% responden menggunakan saliva milik orang yang lebih tua. Saliva orang yang lebih tua biasanya merupakan saliva dari ayah, ibu, kakek, dan nenek pengguna.
Sebanyak 58,06\% responden menyatakan bahwa saliva orang yang lebih tua (bapak, ibu, kakek, nenek) tidak efektif digunakan dalam penyembuhan luka ringan, mereka menganggap bahwa hal tersebut hanya mitos dan saliva siapapun bisa digunakan selagi saliva tersebut higienis. Sebanyak 41,94\% responden menyatakan bahwa saliva orang yang lebih tua (bapak, ibu, kakek, nenek, dll) lebih efektif digunakan dalam penyembuhan luka ringan, karena mereka menganggap bahwa air liur orang tua lebih banyak mengandung basa, tersugesti dari orang tua dan berdasarkan pengalaman.

Menurut Torres et al., (2018), seiring dengan bertambahnya usia, fisiologi organ tubuh manusia akan mengalami penurunan baik karena faktor ilmiah maupun penyakit. Chauncey et. al. (1987) Inayah et. al. (2017) mengemukakan bahwa konsentrasi protein, natrium dan klorida juga nilai osmolalitas dalam saliva menurun seiring dengan bertambahnya usia. Pertambahan usia memberikan dampak pada atropik pada kelenjar submandibular yang menyebabkan terjadinya perubahan komposisi dan penurunan produksi saliva (Arsyad, 2017; Tawas et al., 2018). 


\section{Saliva Orang yang Lebih Tua Lebih Efektif Digunakan untuk Menyembuhkan Luka Ringan}

International Dental Federation (IDF) dalam (Lewapadang, et al (2015), menyatakan bahwa pada populasi manusia dengan usia 40-50 tahun atau lebih, 50\% diantaranya mengalami penuruanan objektif aliran saliva (hiposalivasi) dan pada populasi manusia dengan usia 70 tahun atau lebih akan mengalami peningkatan hingga $70 \%$. Seiring bertambahya usia, fungsi kelenjar saliva akan mengalami penurunan produksi, perubahan komposisi dan fungsi, kelenjar parenkim yang terdapat pada saliva akan hilang dan digantikan dengan jaringan lemak dan jaringan ikat. Penuaan adalah faktor lain yang mempengaruhi produksi histatin, dan hubungan terbalik antara penuaan dan konsentrasi kelenjar histatin.

Pada saat usia semakin menua terjadi perubahan dan penurunan fungsi kelenjar saliva. Kelenjar parenkim hilang yang tergantikan oleh jaringan penyambung dan jaringan lemak, serta terjadi atropi pada lining sel duktus intermediet (Syam et al., 2018) Berdasarkan hasil penelitian yang dilakukan oleh Ayuningtyas et al., (2009), menyatakan bahwasannya pada saat proses penuaan terjadi pada seorang manusia, maka akan terjadi pula perubahan pada kelenjar ludahnya. Perubahan kelenjar ludah yang terjadi adalah jaringan ikat akan bertambah dan sel saline akan berkurang. Sehingga akan mempengaruhi terjadinya perubahan komponen pada saliva, sehingga fungsi saliva akan terganggu dan juga akan menyebabkan penyakit kelainan atau infeksi mudah terjadi.

Kondisi pH saliva pada usia monopause juga mempengaruhi. Monopause yang memiliki penyakit biasanya sekresi pada saliva menurun sehingga menyebabkan $\mathrm{pH}$ pada saliva menjadi rendah dan bisa dikatakan tidak higienis. Namun jika saat monopause dalam keadaan sehat maka kondisi $\mathrm{pH}$ pada saliva akan tetap terjaga (Syahrul et al., 2017). Oleh karena itu anggapan bahwa saliva orang tua lebih efektif untuk digunakan dalam penyembuhan luka merupakan mitos yang tidak dapat dibuktikan secara ilmiah. Sekresi dan konsentrasi saliva berbeda-beda tergantung pada usia dan jenis kelamin. Perubahan komposisi protein saliva memiliki hubungan erat dengan terjadinya penuaan (Hemadi et al., 2017). Berdasarkan hal tersebut, maka pengetahuan masyarakat Lampung terhadap penggunaan saliva orang yang lebih tua untuk menyembuhkan luka dapat direkonstruksi menjadi penggunaan saliva milik siapapun (tidak terbatas pada orang tua) untuk menyembuhkan luka ringan.

\section{Sumber Pengetahuan Penggunaan Saliva Sebagai Obat Penyembuh Luka Ringan}

Berdasarkan Gambar 1 diketahui bahwa responden yang mengetahui bahwa saliva dapat dijadikan sebagai penyembuh luka yakni sebanyak $48,39 \%$ dari orang tua, $22,58 \%$ dari teman, $19,34 \%$ dari inisiatif diri sendiri dan 9,68\% dari artikel ilmiah.

Pengetahuan masyarakat Jayasakti, Anak Tuha, dalam penggunaan saliva pada penyembuhan luka ringan yang paling banyak bersumber dari orang tua. Hal ini menandakan bahwa penggunaan saliva pada penyembuhan luka ringan sudah dilakukan secara turun menurun. Menurut Neves et al. (2019), menyembuhan luka dengan saliva telah dilakukan oleh masyarakat Yunani kuno 2.000 tahun yang lalu ketika mereka menggunakan air liur ular pada luka terbuka untuk meningkatkan penyembuhan luka pada kulit 
Tabel 2

Pengetahuan masyarakat Lampung Tengah pada penyembuhan luka ringan menggunakan saliva

\begin{tabular}{|c|c|c|c|}
\hline No. & $\begin{array}{l}\text { Pertanyaan pengetahuan penggunaan } \\
\text { saliva untuk penyembuhan luka ringan }\end{array}$ & Pres & e (\%) \\
\hline \multirow[t]{4}{*}{1.} & \multirow[t]{4}{*}{ Alasan Menggunakan saliva } & $87,10 \%$ & $12,90 \%$ \\
\hline & & Mengikuti & Mengetahui \\
\hline & & kebiasaan & kandungannya \\
\hline & & masyarakat & $\begin{array}{l}\text { (histatin dan } \\
\text { asam basa) }\end{array}$ \\
\hline \multirow[t]{2}{*}{2.} & \multirow{2}{*}{$\begin{array}{l}\text { Pengetahuan } \\
\text { saliva }\end{array}$} & $74,19 \%$ & $25,81 \%$ \\
\hline & & $\begin{array}{l}\text { Tidak } \\
\text { mengetahui }\end{array}$ & Mengetahui \\
\hline \multirow[t]{2}{*}{3.} & \multirow{2}{*}{$\begin{array}{l}\text { Keefektifan saliva yang } \\
\text { pada penyembuhan luka }\end{array}$} & $67,74 \%$ & $32,26 \%$ \\
\hline & & Efektif & Tidak efektif \\
\hline
\end{tabular}

Berdasarkan Tabel 2, pengetahuan masyarakat Lampung Tengah pada penyembuhan luka ringan menggunakan saliva diketahui bahwa sebagian besar masyarakat menggunakan saliva sebagai penyembuh luka hanya karena mengikuti kebiasaan turun menurun dari nenek moyang, bukan karena mengetahui kandungan saliva yang dapat menjadi obat penyembuh luka. Hal tersebut dinyatakan dengan respon $87,10 \%$ responden yang menggunakan saliva sebagai obat penyembuhan luka karena mengikuti kebiasaan masyarakat, sedangkan 12,90\% responden yang menggunakan saliva sebagai obat penyembuhan luka karena mengetahui kandungan dan manfaat air liur tersebut. Sebanyak 74,19\% responden tidak mengetahui kandungan saliva sedangkan sebanyak $25,81 \%$ responden yang mengetahui kandungan saliva. Responden yang mengetahui kandungan saliva menyatakan bahwa kandungan saliva yang dapat menyembuhkan luka yaitu histatin dan asam basa.

\section{Kandungan Saliva yang Berfungsi Sebagai Obat Penyembuh Luka Ringan}

Berbagai zat biologis yang terkandung dalam saliva berfungsi dalam pelumasan, aktivitas antimikroba, aktivitas antioksidan, respon inflamasi dan imun serta penyembuhan luka (Abbasian et al., 2010). Berdasarkan penelitian yang dilakukan oleh Andika, et al., (2014), diketahui bahwa kadar natrium bikarbonat pada saliva dapat mempertahankan sistem buffer dalam rongga mulut sehingga $\mathrm{pH}$ keasamannya tetap terjaga. Saliva berfungsi untuk membentuk lapisan mukus pelindung pada membran mukosa yang akan bertindak sebagai barrier terhadap iritan, mencegah kekeringan, membantu membersihkan mulut, dari makanan, debris dan bakteri. Selain itu saliva juga dapat mengatur $\mathrm{pH}$ rongga mulut, membantu menjaga integritas gigi dengan berbagai cara karena kandungan kalsium dan fosfatnya mampu melakukan aktivitas antibakteri dan antivirus (Syahrul et al., 2017). Saliva bersifat sebagai pelindung mukosa mulut dari kolonisasi bakteri yang disebabkan karena adanya kandungan mucin, enzim dan IgA (Destri et al., 2017). Saliva memiliki fungsi protektif melalui antibodi yang khusus terhadap mikroorganisme dan melalui berbagai komponen antimicrobial, misalnya lisozim, 
musin, laktoferin dan histatin (Arsyad, 2017)

Saliva merupakan sumber faktor pertumbuhan yang dapat memacu fase proliferasi penyembuhan luka. Faktor pertumbuhan yang terdapat di dalam saliva antara lain insulinlike growth factor I and II (IGF-I, IGF-II), epidermal growth factor (EGF), transforming growth factor alpha and beta (TGF-a TGF-\$), nerve growth factor (NGF) dan basic fibroblast growth factor (bFGF). Faktor-faktor pertumbuhan tersebut mendorong berbagai sel inflamatorik ke daerah luka, menginduksi proliferasi keratinosit dan fibroblast, angiogenesis dan jaringan granulasi. Meskipun memiliki jumlah yang sedikit, tetapi faktor-faktor pertumbuhan tersebut memiliki peran yang besar dalam penyembuhan luka. Selain itu, saliva juga memiliki kandungan IgG, IgA dan IgM serta komponen antimicrobial seperti histatin, musin, laktoferin dan lisozom. Saliva juga mengandung protein yang memiliki peran peting dalam berbagai tahap penyembuha luka intraoral. Pada hewan, kelenjar sublingual dan submandibular merupakan kelenjar yang memiliki peran utama dalam penyembuhan luka pada mukosa oral atu kulit (Fajarwati et al., 2015). Menurut Abiko \& Selimovic (2010), pada saliva juga terkandung faktor pertumbuhan trombosit (PDGF). PDGF berfungsi untuk meningkatkan vaskularisasi dan deposisi matriks ekstraseluler.

Menurut Tripathi et al. (2015), EGF merupakan salah satu unsur penting dari air liur yang berfungsi meningkatkan penyembuhan dini luka kulit. Selama tahun 1999 hingga 2006, EGF yang mengandung salep menjadi standar terbaik untuk mempercepat penyembuhan luka diabetes. Pada hewan, EGF diperkirakan menjadi penyumbang utama efek penyembuhan luka dari air liur (Shah et al., 2020) Sedangkan pada manusia, terdapat EGF dan Histatin yang dapat meningkatkan migrasi sel epitel, tetapi histatin memiliki konsentrasi yang jauh lebih tinggi dibandingkan dengan EGF (Oudhoff et al., 2009).

Histatin merupakan peptida kationik yang terdapat dalam saliva yang muncul sebagai modulator penting dalam penyembuhan luka epitel, dan lebih khusus lagi, selama respons migrasi sel yang terlibat dalam perbaikan jaringan. Kandungan saliva terutama histatin berperan utama dalam meningkatkan penyembuhan luka dengan meningkatkan fase repitelisasi, terutama melalui peningkatan migrasi dan proliferasi keratinosit. Histatin memiliki sifat antimikroba dan antijamur yang memainkan beberapa peran penting seperti imunitas bawaan dan memerangi patogen asing yang menyerang, penyembuhan luka, dan apoptosis (Kusuma, 2015). Histatin memiliki spectrum antimikroba yang luas, termasuk aktivitas anti-kandidial. Muatan positif yang kuat dari histatin mengangu membran sel mikroba. Penghambatan pelepasan mediator sel mast oral oleh histatin menunjukkan adanya fungsi antiinflamasi (Pandey, 2014).

Salah satu ciri khas dari mukosa mulut manusia adalah tingkat pergantiannya yang tinggi karena keberadaan banyak faktor seperti adanya Histatin-1 dan Histatin-2 (Kusuma, 2015). Keluarga Histatin mengandung dua gen (HTN1 dan HTN3) dan 13 produk protein (Shah et al., 2020). Bentuk utama dari histatin manusia adalah Histatin1, Histatin-3 dan Histatin-5 dengan kontribusi individu sekitar 20-30\% terhadap total kumpulan histatin. Histatin-1 terdiri atas serin terfosforilasi pada residu nomor 2 yang dapat meningkatkan afinitas peptida untuk berasosiasi dengan kristal HA. Menurut Sultan et al. (2019) tidak semua 
histatin mendorong migrasi sel, Hst1, Hst2 dan Hst3, tetapi tidak pada Hst5, telah terbukti efektif mendorong migrasi keratinosit oral yang berperan dalam penyembuhan luka yang dikaitkan dengan C-terminalnya. Namun hasil penelitian Shah et al., (2020), menunjukkan bahwa Hst5 dapat meningkatkan migrasi sel, dengan ukuran efek yang sama dengan peptide histatin lainnya. Selain itu, serupa dengan Hst1, Hst5 tampaknya dapat meningkatkan penyebaran sel.

Pada saliva juga terkandung opiorphin, yaitu zat pembunuh rasa sakit alami yang ampuh, senyawa endogen ini pertama kali diisolasi dari air liur manusia. Opiorphin memperpanjang pertahanan tubuh dengan mencegah pemecahan bahan kimia yang mengaktifkan reseptor opiate yang menghalangi sinyal rasa sakit mencapai otak (Vila et al., 2019).

Saliva juga mengandung substansi yang bersifat antibakterial, seperti Lyzozime yang berfungsi mendegredasi dan mengikat membran bakteri; Laktoferin yang berfungsi untuk mengurangi ion Fe yang dibutuhkan bakteri; dan enzim Laktoperoksidase yang berfungsi dalam pemanfaatan $\mathrm{H}_{2} \mathrm{O}_{2}$ untuk menghasikan agen oksidasi yang dapat merusak sistem enzim yang terdapat pada bakteri. Enzim amylase dalam saliva juga berfungsi mencegah adhesi bakteri pada jaringan mukosa oral dan jika enzim amilase serta Mucin-1 berasosiasi maka akan menghilangkan bakteri yang berada dalam saliva. Selain itu, zat Cystatin dalam saliva bersifat antibakteri terhadap P. ginggivalls dan immunoglobulin berfungsi untuk mencegah kolonisasi bakteri dan berasosiasi dengan Mucin untuk mengambat pertumbuhan bakteri (Kusuma, 2015). Menurut Abbasian et al. (2010), lisozim dapat meningkatkan penyembuhan luka dengan menekan terjadinya infeksi.
Selama penyembuhan luka, terjadi proses angionenesis. Angiogenesis adalah pertumbuhan pembuluh darah yang baru dari kapiler yang sudah ada sebelumnya. Angiogenesis terjadi jika terdapat senyawa yang merangsang angioneseis (proangionik) (Inayah et. al., 2017). Proses angiogenesis berperan penting dalam pengiriman nutrisi dan oksigen ke sel-sel luka (Mi et al., 2020).

Menurut Cristina Destri dkk (2017) proses penyembuhan luka melibatkan beberapa fase Penyembuhan luka melibatkan empat fase yang tumpang tindih yaitu sebagai berikut :

\section{Fase Hemostatis}

Pada fase ini proses penyembuhan luka diawali oleh pembekuan darah sebagai kegiatan awal dalam menutup luka. Aktivasi trombosit selama fase homeostasis akan melepaskan sejumlah sitokinin yang penting dalam mengawali proses penyembuhan melalui signal kemotaktik yang akan ditujukan kepada sel-sel inflamasi dan sel residen. Selain itu pembekuan fibrin fibronektin berfungsi sebagai provisional matrik dari sel epitel dan fibroblast untuk dapat migrasi menuju area luka. Pelepasan sitokinin selama fase pembekuan mengawali reaksi inflamasi sebagai penyedia debridement dengan menghilangkan jaringan yang rusak dan mikroba. Selama dalam proses respon imun innate ini terjadi sel-sel inflamasi yang telah di ambil pada area luka akan melepaskan lebih banyak lagi sitokinin dan kemokin yang berfungsi untuk memodulasi penyembuhan luka.

\section{Fase Inflamasi}

Pada fase ini awalnya dimulai saat netrophil melekat pada endothelium sesaat setelah trauma. Netrophil dengan elastse dan kolagenase memfasilitasi migrasi 
menuju bagian ekstra selular. Dimana sel akan memfagositosis bakteri, degradasi matrik protein serta menarik penambahan netrophil dan makrofage. Sel inflamasi yang paling berperan yaitu sel makrofage akan mendominasi area luka dari hari ke-3 sampai hari ke-5.

Pada 6-8 jam setelah luka, pembuluh darah yang telah rusak akan mengeluarkan plasma dan netrophil ke area luka. Netrophil akan memulai mencerna dan membersihkan sel debris dan sel asing sehingga netrophil akan mengalami apoptosis dan perannya digantikan oleh makrofage. Degradasi produk fibrin akan berfungsi sebagai kemotaktik sel fibroblast dan sel epitel ke area luka.

\section{Fase Proliferasi}

Pada fase ini didalamnya meliputi fibroplasia, granulasi, epitelisasi dan angiogenesis yang akan dimulai pada $24 \mathrm{jam}$ setelah trauma. Matrik fibrin sebagai tempat migrasi keratinosit dimana sebagian sel ini di stimulan oleh TGF-B yang akan bergerak dari tepian luka dan folikel rambut menggeser keratinosit yang telah ada di sekitar area luka dengan melompat. Disaat waktu yang bersamaan VEGF diinduksi oksigen yang rendah akan mempromosi angiogenesis dan mempengaruhi sel endotel kapiler terdekat untuk di rekrut dan di stimulasi untuk berproliferasi. Platelet derived growth factor akan mengatur fibroblast yang pindah pada 48 jam hingga 72 jam setelah terjadi luka untuk mengalami proliferasi matrik dermal.

\section{Fase Remodeling}

Pada fase ini penyembuhan luka membutuhkan waktu beberapa minggu hingga tahun. Karena kontraksi luka dimulai pada hari ke-5 karena adanya perubahan fenotip fibroblast menjadi actin-laden myofibroblast. Proses kontraksi akan menarik tepian luka untuk saling mendekat, menutupi area permukaan dan meningkatkan kecepatan penutupan luka. Kontraksi luka secara efektif di mediasi oleh myofibroblast yang berdifferensiasi dengan menggunakan reseptor integrin untuk menarik matrik mengunakan kekuatan sitoskeleton yang memiliki banyak aktin. Myofibroblast berdiferensiasi dari residen fibroblast local atau sel progenitor lain denga molekul matrik tertentu dengan growth factor seperti EDA-fibronektin dan TGF-B.

Saliva meningkatkan respons inflamasi bawaan (peningkatan CCL20, IL-6, dan CXCL-8 sekresi) bila dioleskan secara topikal ke area mengapit yang layak dari kulit manusia yang direkonstruksi dan mukosa mulut tanpa mengubah profil diferensiasi keratin spesifik kulit (Neves et al., 2019).

Menurut pengetahuan para responden menunjukkan bahwa sebanyak 67,74\% responden percaya saliva efektif digunakan sebagai obat penyembuh luka berdasarkan pengalaman mereka ketika menggunakannya, dann sebanyak 32,26\% responden menyatakan saliva tidak efektif digunakan sebagai obat penyembuh luka karena belum mengetahui kandungan saliva dan menganggapnya hanya sebagai sugesti. Fakta bahwa kebanyakan masyarakat Lampung yang hanya mengikuti kebiasaan jaman dahulu dalam penggunaan saliva untuk menyembuhkan luka dan disisi lain tidak mengetahui kandungan saliva namun mengakui keefektifannya menunjukkan bahwa penggunaan saliva merupakan pengetahuan asli masyarakat yang dapat ditarik alasan ilmiahnya yakni adanya kandungan histatin dan enzim-enzim untuk penyembuhan luka. 


\section{Simpulan}

Dari hasil penelitian dapat disimpulkan bahwa penggunaan saliva dalam penyembuhan luka ringan di Lampung merupakan kebiasaan turun-termurun yang dapat direkonstruksi alasan ilmiahnya yaitu saliva memilki kandungan histatin dan enzim-enzim untuk penyembuhan luka. Dengan demikian, kajian ini dapat memberikan informasi ilmiah bahwa keefektifan saliva tidak berdasarkan sugesti semata melainkan keberadaan zat-zat dalam saliva yang dapat digunakan sebagai obat penyembuh luka ringan. Penelitian ini memberikan pandangan lebih lanjut bahwa uji kandungan saliva orang-orang yang berbeda kondisi fisiologisnya untuk penyembuhan luka ringan sangat penting ditindaklanjuti.

\section{Ucapan Terima Kasih}

Terima kasih kepada ibu Hafidha Asni Akmalia selaku Dosen Pembimbing Lapangan dan semua pihak yang telah membantu dalam menyelesaikan penelitian ini.

\section{Daftar Pustaka}

Abbasian, B., Azizi, S., \& Esmaeili, A. (2010). Effects of Rat 's Licking Behavior on Cutaneous Wound Healing. 13(1), 242-247.

Abiko, Y., \& Selimovic, D. (n.d.). The Mechanism of Protracted Wound Healing On Oral Mucosa In Diabetes . Review. 10(3), 186-191.

Andika, M., Prasko, S., \& Hermien, S. (2014). Pengaruh Berkumur Air Rebusan Cabe Jawa Terhadap Ph Saliva. Kesehatan Gigi, 2(2), 239-244.

Ayuningtyas, G., Harijanti, K., \& Soemarijah, S. (2009). Sekresi saliva menurun dan terjadinya kandidiasis oral pada orang tua ( Penurunan sekresi saliva dan munculnya kandidosis oral pada orang tua ). 1, 6-10.

Brand, H. S., Ligtenberg, A. J. M., \& Veerman, E. C. I. (2014). Saliva and wound healing. Monographs in Oral Science, 24 , $52-60$. https://doi.org/10.1159/000358784

Darmastuti, R. dan D. K. S. (2011). Kekuatan Kearifan Lokal Dalam Komunikasi Kesehatan. Jurnal Komunikasi. Jurnal Komunikasi, 3(2), 233-244.

Destri, C., Nugraha, J., Anatomi, D. P., Kedokteran, F., Surabaya, U. A., Klinik, D. P., Kedokteran, F., \& Surabaya, U. A. (2017). Potensi Jatropha multifida Terhadap Jumlah Fibroblast Pada Aphthous Ulcer. 19(1).

Fajarwati, R., Utami, L., Ip, V. T., Wirohadidjojo, Y. W., Ilmu, B., Kulit, K., Universitas, F. K., Mada, G., \& Sardjito, R. (2015). Efek Saliva Manusia Pada Proliferasi Dan Migrasi Fibroblas Jaringan Kulit Normal. Media DermatoVenereologica Indonesiana, 42, 2-6.

Gibbs, S., Roffe, S., Meyer, M., \& Gasser, A. (2019). Biology of soft tissue repair: Gingival epithelium in wound healing and attachment to the tooth and abutment surface. European Cells and Materials, 38, 63-78. https://doi.org/10.22203/eCM.v038a 06

Hemadi, A. S., Huang, R., Zhou, Y., \& Zou, J. (2017). Salivary proteins and microbiota as biomarkers for early childhood caries risk assessment. Nature Publishing Group, 9(11), 1-8. https://doi.org/10.1038/ijos.2017.35

Kavanagh, K., \& Dowd, S. (2004). Histatins: antimicrobial peptides with therapeutic potential. Journal of Pharmacy and Pharmacology, 56(3), 285-289.

https://doi.org/10.1211/002235702 
2971

Kumar, B., Kashyap, N., Avinash, A., \& et al. (2017). The composition, function and role of saliva in maintaining oral health: A review. Int J Contemp Dent Med Rev, 1-6. https://doi.org/10.15713/ins.ijcdmr.1 21

Kusuma, N. (2015). Fisiologi dan Patologi Saliva. Andalas University Press.

Lesmana, H., Alfianur, A., Utami, P. A., Retnowati, Y., \& Darni, D. (2018). Pengobatan tradisional pada masyarakat tidung kota Tarakan: study kualitatif kearifan lokal bidang kesehatan. Medisains, 16(1), 31. https://doi.org/10.30595/medisains. v16i1.2161

Lewapadang, Wanda, Tendean, Lydia E. N., P. S. A. (2015). Pengaruh Mengonsumsi Nanas (Ananas Comosus) Terhadap Laju Aliran Saliva Pada Lansia Penderita Xerostomia. E-GiGi (EG), 3(2), 454-458.

Mintjelungan, C. N., \& Pangemanan, D. H. C. (n.d.). Xerostomia pada Usia Lanjut di Kelurahan Malalayang Satu Timur. 14.

Moleong, L. J. (2012). Metodologi Penelitian Kualitatif. PT Remaja Rosdakarya.

Nanobiotechnol, J., Mi, B., Chen, L., Xiong, Y., Yan, C., Xue, H., Panayi, A. C., \& Liu, J. (2020). Saliva exosomes - derived UBE2O mRNA promotes angiogenesis in cutaneous wounds by targeting SMAD6. Journal of Nanobiotechnology,1-14. https://doi.org/10.1186/s12951020-00624-3

Oudhoff, M. J., Kroeze, K. L., Nazmi, K., Keijbus, P. A. M., Hof, W., FernandezBorja, M., Hordijk, P. L., Gibbs, S., Bolscher, J. G. M., \& Veerman, E. C. I. (2009). Structure-activity analysis of histatin, a potent wound healing peptide from human saliva: cyclization of histatin potentiates molar activity 1000 -fold. The FASEB Journal, 23(11), 3928-3935.

https://doi.org/10.1096/fj.09-137588

Pandey, A. K., \& Pandey, A. K. (2014). Physiology of Saliva: An Overview Physiology of Saliva: An Overview.21(1). https://doi.org/10.14693/jdi.v0i0.18 6

Pertiwi,U. D., \& Rusyda Firdausi, U.Y.(2019). Upaya Meningkatkan Literasi Sains Melalui Pembelajaran Berbasis Etnosains. Indonesian Journal of Natural Science Education (IJNSE), 2(1),120-124.

https://doi.org/10.31002/nse.v2i1.47 6

Publisher, S., Resident, S. S., Maxillofacial, O., \& Divison, S. (2015). Case Report Management of Non Healing Oral Ulcer in Diabetic Patient Using Topical Application of Epidermal Growth Factor : A Case Report. 3(8), 640-643.

Rahmawati, I., Said, F., \& Hidayati, S. (2015). Perbedaan pH Saliva Sebelum dan Sesudah Mengonsumsi Minuman Ringan. Jurnal Skala Kesehatan, 6(1), 11.

Rodrigues Neves, C., Buskermolen, J., Roffel, S., Waaijman, T., Thon, M., Veerman, E., \& Gibbs, S. (2019). Human saliva stimulates skin and oral wound healing in vitro. Journal of Tissue Engineering and Regenerative Medicine, 13(6),1079-1092.

https://doi.org/10.1002/term.2865

Saliva, P., Gekko, T., \& Angiogenesis, L. T. (2017). Effect of Tokay Gecko ( Gekko gecko LINNAEUS , 1758 ) Saliva on Angiogenesis During Wound Healing Phase of Autotomized Tail in Common Sun Skink ( Eutropis multifasciata KUHL , 1820 ). 13(2), 253-260. 
Sarah J. Lowry, Hillary Blecker, Janice Camp, Butch De Castro, Steven Hecker, Saman Arbabi, Neal Traven, N. S. S. (2017). Possibilities and challenges in occupational injury surveillance of day laborers. Occupational Medicine, 53(4), 130.

Shah, D., Son, K., Kalmodia, S., Lee, B., Ali, M., Balasubramaniam, A., Shukla, D., \& Aakalu, V. K. (2020). Wound Healing Properties of Histatin-5 and Identification of a Functional Domain Required for Histatin-5-Induced Cell Migration. Molecular Therapy: Methods \& Clinical Development, 17(June), 709-716. https://doi.org/10.1016/j.omtm.2020 .03 .027

Sultan, A. S. (2019). crossm Evaluation of the Antifungal and Wound-Healing Properties of a Novel Peptide-Based Bioadhesive Hydrogel Formulation. 63(10), 1-11.

Susanti, S. (2016). Pemetaan Penyakit Pneumonia di Provinsi Jawa Timur. Biometrika Dan Kependudukan, 5(2), 117-124.

Syahrul, D., Dewi, T. P., \& Sulistyawati, I., \& O., G. A. P. (2017). Peranan Madu $15 \%$ Terhadap Peningkatan pH Saliva Wanita Menopause. Interdental, 9-14.

Torres, P., Castro, M., Reyes, M., \& Torres, V. A. (2018). Histatins, wound healing, and cell migration. Oral Diseases, 24(7),1150- 1160.https://doi.org/10.1111/odi.12 816

Tubert-Brohman, Ivan \& Sherman, Woody \& Repasky, Matthew \& Beuming, $\mathrm{T}$. (2013). ). Improved Docking of Polypeptides with Glide. Journal of Chemical Information and Modeling, 53(9), 1689-1699.

Verrier L. (1970). Dog Licks Man. Lancet, 1, 5.Vila, T., Rizk, A. M., Sultan, A. S., \& Jabra-Rizk, M. A. (2019).

The power of saliva: Antimicrobial and beyond. PLoS Pathogens, 15(11), 1016.

https://doi.org/10.1371/journal.ppat. 1008058

Wahyudi, I. A., Magista, M., \& Angel, M. (2013). Efektivitas Penggunaan Saliva Dibandingkan Povidin-Iodin $10 \%$ Terhadap PenyembuhanLuka Pada Kutaneus Tikus Sprague Dawley The Effectiveness Of Saliva Compare To10 $\%$ Povidin- Iodine Of Healing Injury In Rats Cutaneous Sprague Dawley. Jurnal Universitas Muhammadiyah Yogyakarta, 2(1), 1-12.

Wojcicki, J. M. (2003). Traditional behavioural

practices, the exchange of saliva and HHV-8 transmission in sub-Saharan African populations. British Journal of Cancer, 89(10),2016-2017. https://doi.org/10.1038/sj.bjc.66013 90 